\title{
Analisis kinerja pelayanan publik pengurusan Surat Ijin Mengemudi berbasis teknologi informasi
}

\section{Performance analysis of information-technology-based public service on Driving License issuance}

\author{
$\operatorname{Arpan}^{凶}$ \\ Polresta Kediri \\ Kediri, 64114, Jawa Timur, Indonesia \\ E-mail corresponding author: arpan-2015@pasca.unair.ac.id
}

\begin{abstract}
Abstrak
Penilaian kinerja penerbitan SIM sistem online dengan prinsip layanan prima di Satpas Polresta Sidoarjo dilakukan berdasarkan 9 indikator sebagaimana pendapat Bob Livingston. Hasil dari indikator ini: "Melebihi harapan", yang mana dalam kriteria ini terdapat beberapa orang yang kurang puas terhadap aplikasi e-SIM Sidoarjo yang dianggap sering bermasalah, mengalami penutupan paksa, maupun kurangnya menu dalam aplikasi sehingga harapan yang tinggi oleh masyarakat belum mencapai potensi yang sepenuhnya. Metode yang digunakan dalam penelitian ini adalah metode kualitatif deskriptif. Hasil penelitian ini menunjukkan bahwa dalam hal "menangani pengaduan" saat ini pengaduan tidak dapat dilakukan secara online melalui aplikasi eSIM Sidoarjo. Meskipun begitu, menurut penulis pengaduan online penting untuk diintegrasikan dalam aplikasi untuk memaksimalkan layanan kepada masyarakat. Pelayanan e-SIM Sidoarjo menurut indikator Livingston yaitu: "melebihi harapan". Standarisasi pelayanan yang diberikan oleh petugas Polresta Sidoarjo, sikap perhatian dan pelayanan yang bermutu tinggi menimbulkan kepuasan masyarakat menjadi patokan penting dalam pelayanan yang melebihi harapan.
\end{abstract}

Kata kunci: kinerja; pelayanan; e-SIM; integrasi; kepolisian

\begin{abstract}
The performance evaluation of driving license online issuance (e-SIM) service at the Administrator Division of Sidoarjo Police Department is administered under the principle of excellent service. It is also done based on the nine indicators according to Bob Livingston with results indicating the service as 'exceeding expectations'. That being said, there are some who are dissatisfied with the e-SIM application for various reasons: they experience problems in using the app; the app force close by itself; and its lack of menus. These problems have rendered the app unable to show its full potential to live up to the expectation of its users. The present study aims to address this issue through a descriptive qualitative method. Results show that the service is running poorly in terms of 'handling complaint'. This is due to the unavailability of online complaint menu in the app. The author argues that an online complaint needs to be integrated in the app to maximize its service. However, the overall service is indicated as 'exceeding expectations' due to the high service standards of the members of the force, their good attitude and attention, and the high quality service they have given. These factors contribute in the satisfaction of the service users, which is an important criterion in a service that exceeds expectations.
\end{abstract}

Keywords: performance; excellent service; e-SIM; integration; police

\section{Pendahuluan}

Penataan sistem manajemen dan prosedur kerja di lingkungan pemerintah, bisnis, institusi pendidikan dapat terwujud melalui optimalisasi pelayanan publik berbasis elektronik (Susanti 2006; Fahlefi 2014; Angguna et al. 2016; Bressolles \& Nantel 2008; Yih Goh et al. 2011; Lee \& Lin 2005; Sunanto et al. 2007; Al Nuami et al. 2014; Fassnacht \& Koese 2006; Mukarom 2015). Pelayanan SIM berbasis teknologi informasi adalah pelayanan prima yang menggunakan perangkat komputer dengan sistem online antar semua perangkat komputer yang mampu mempercepat proses pelayanan dan menghemat tenaga personel (Indrajit 2006; Iswahyudi 2014; Gemilang 2016; Prabowo \& Irwansyah 2018; Wiyono et al. 2012). Beda dengan pelayanan konvensional yang merupakan pelayanan SIM dengan menggunakan sistem lama/manual dengan mengandalkan keterlibatan langsung personil dalam memberikan nilai ujian kepada pemohonK, keunggulan pelayanan SIM berbasis teknologi informasi di Satpas Polresta Sidoarjo ini antara lain pendaftaran online, one gate system, tanda tangan dan sidik jari 
elektronik, ujian teori menggunakan komputer, sistem antrian digital, sistem pemanggilan dengan FIFO. Program SIM berbasis tekonologi Informasi ini menargetkan pencapaian keunggulan (Strive for exellence) untuk membangun kepercayaan masyarakat (Juwita 2018).

Optimalisasi kinerja pelayanan SIM serta tercapainya kepuasan masyarakat adalah tujuan pelayanan SIM berbasis tekonologi informasi di Satuan Penyelenggara Administrasi (Satpas) Polresta Sidoarjo. Optimalisasi kinerja menuntut pola yang profesional, transparan, akuntabel dan moderen seluruh sumber daya di Satpas Polresta Sidoarjo guna mendukung tugas Polri (Febrianti \& Maulana 2013). Menurut Mangkunegara (2009) istilah kinerja berasal dari kata Job Performance atau Actual Performance (prestasi kerja atau prestasi sesungguhnya yang dicapai oleh seseorang). Selain itu kinerja juga merupakan hasil kerja secara kualitas dan kuantitas yang dicapai oleh seorang pegawai dalam melaksanakan tugasnya sesuai dengan tanggung jawab yang diberikan kepadanya (Mangkunegara 2009; Dewanto 2018). Menurut Tejo dan Machasin (2015) kemampuan teknis personil dalam penggunaan teknologi informasi yang masih lemah mempengaruhi kinerja dan budaya kinerja dalam organisasi, sehingga berdampak pada optimalisasi pelayanan. Dalam mengetahui optimalisasi kinerja, penulis juga melakukan kajian terhadap kepuasan masyarakat yang memanfaatkan pelayanan SIM berbasis tekonologi informasi (online) di Satpas Polresta Sidoarjo. Tujuan dari pengukuran kepuasan masyarakat ini adalah untuk mengetahui tingkat kepuasan masyarakat secara berkala dan mengetahui kecenderungan kinerja pelayanan Satpas secara berkala dan sebagai bahan untuk menetapkan kebijakan dalam rangka peningkatan kualitas pelayanan publik selanjutnya.

Sementara itu, kinerja pimpinan adalah satu ukuran tentang bagaimana pimpinan secara efektif melaksanakan tugas- tugas dan secara efisien menggunakan sumber-sumber untuk mencapai tujuantujuan organisasional melalui pelaksanaan fungsi-fungsi manajemen. Di banyak organisasi, kinerja merupakan faktor utama yang menentukan keberhasi dalam organisasi. Seberapa baik para anggota organisasi melakukan pekerjaan mereka secara signifikan mempengaruhi produktivitas dan kinerja organisasional (Silalahi 2011).

Indikator Pelayanan Prima menurut Fitzsimmons mengemukakan lima indikator pelayanan publik, yaitu: (1) Reliability yang ditandai pemberian pelayanan yang tepat dan benar; (2) Tangibles yang ditandai dengan penyediaan yang memadai sumber daya lainnya; (3) Responsiveness, yang ditandai dengan keinginan melayani konsumen dengan cepat; (4) Assurance, yang ditandai tingkat perhatian terhadap etika dan moral dalam memberikan pelayanan; (5) Empati, yang ditandai tingkat kemauan untuk mengetahui keinginan dan kebutuhan konsumen (Sinambela 2006; Sinambela 2014).

Sedangkan untuk indikator yang digunakan penulis dalam penelitian ini adalah menggunakan 9 indikator menurut Bob Livingston yakni: a) Melebihi harapan; b) Menyelesaikan konflik dan memecahkan masalah; c) Menangani pengaduan; d) Berkomunikasi dengan baik; e) Berfokus pada pelanggan yang dilayani; f) Pemberdayaan; g) Berbaur dengan semua orang; h) Mengatur waktu; i) Bisa dipercaya (Livingston 2008).

Setiap penyelenggara pelayanan publik wajib melakukan survei kepuasan masyarakat secara berkala minimal 1 (satu) kali setahun. Survei kepuasan masyarakat yang dilakukan terhadap unit penyelenggaraan pelayanan publik menggunakan indikator dan metodologi survei yang sudah ditentukan. Adapun indikator IKM sebagaimana Peraturan Menteri Pendayagunaan Aparatur Negara dan Reformasi Birokrasi Republik Indonesia Nomor 14 Tahun 2017 adalah: (1) Persyaratan persyaratan adalah syarat yang harus dipenuhi dalam pengurusan suatu jenis pelayanan, baik persyaratan teknis maupun administratif; (2) Sistem, mekanisme, dan prosedur, prosedur adalah tata cara pelayanan yang dibakukan bagi pemberi dan penerima pelayanan, termasuk pengaduan; (3) Waktu penyelesaian, waktu Penyelesaian adalah jangka waktu yang diperlukan untuk menyelesaikan seluruh proses pelayanan dari setiap jenis pelayanan; (4) Biaya/Tarif, biaya/tarif adalah ongkos yang dikenakan kepada penerima layanan dalam mengurus dan/atau memperoleh pelayanan dari penyelenggara yang besarnya ditetapkan berdasarkan kesepakatan antara penyelenggara dan masyarakat; (5) Produk spesifikasi jenis pelayanan, produk spesifikasi jenis pelayanan adalah hasil 
pelayanan yang diberikan dan diterima sesuai dengan ketentuan yang telah ditetapkan. Produk pelayanan ini merupakan hasil dari setiap spesifikasi jenis pelayanan; (6) Kompetensi pelaksana, kompetensi pelaksana adalah kemampuan yang harus dimiliki oleh pelaksana meliputi pengetahuan, keahlian, keterampilan, dan pengalaman. (7) Perilaku pelaksana, perilaku pelaksana adalah sikap petugas dalam memberikan pelayanan. (8) Penanganan pengaduan, saran dan masukan, penanganan pengaduan, saran dan masukan, adalah tata cara pelaksanaan penanganan pengaduan dan tindak lanjut; (9) Sarana dan prasarana, sarana adalah segala sesuatu yang dapat dipakai sebagai alat dalam mencapai maksud dan tujuan. Prasarana adalah segala sesuatu yang merupakan penunjang utama terselenggaranya suatu proses (usaha, pembangunan, proyek). Sarana digunakan untuk benda yang bergerak (komputer, mesin) dan prasarana untuk benda yang tidak bergerak (gedung).

\section{Metode Penelitian}

Penelitian ini menggunakan pendekatan kualitatif dengan sifat deskriptif. Menurut Bogdan dan Taylor, metode kualitatif sebagai prosedur penelitian yang menghasilkan data deskriptif berupa kata-kata tertulis atau lisan dari orang-orang dan perilaku yang dapat diamati (Moleong 2014). Populasi dalam penelitian ini adalah seluruh masyarakat yang berkunjung ke Satpas Polresta Sidoarjo guna mendapatkan pelayanan penerbitan SIM dengan jumlah Sampel sebanyak 150 responden/pemohon SIM yang dipilih secara random sampling berdasarkan data yang masuk melalui Kios Komputer (Kios-K) yang didalamnya terdapat aplikasi elektronik Survey Kepuasan Masyarakat (e-SKM) pada bulan Juli tahun 2018 sampai dengan Desember 2018, yang indikator kuesionernya berdasarkan pada Permenpan RB No. 14 Tahun 2017 tentang Pedoman Penyusunan Survei Kepuasan Masyarakat Unit Penyelenggara Pelayanan Publik dengan 9 indikator penilaian antara lain: a) persyaratan; b) sistem, mekanisme, dan prosedur; c) waktu penyelesaian; d) biaya/tarif; e) produk spesifikasi jenis pelayanan; f) kompetensi pelaksana; g) perilaku pelaksana; h) penanganan pengaduan, saran dan masukan; i) sarana dan prasarana.

Dalam pengolahan data Nilai indeks Kepuasan Masyarakat (IKM) dihitung dengan menggunakan "nilai rata - rata penimbang" masing - masing unsur pelayanan. Dalam perhitungan Survei Kepuasan Masyarakat (SKM) terhadap 9 (sembilan) unsur pelayanan yang dikaji, setiap unsur pelayanan memiliki penimbang yang sama dengan rumus pada Gambar 1.

$$
\begin{array}{|c|c|}
\begin{array}{c}
\text { Bobot Nilai rata }- \text { rata } \\
\text { Tertimbang }
\end{array} & =\frac{\text { Jumlah bobot }}{\text { Jumlah unsur }}=\frac{1}{9}=0,111 \\
\text { Gambar } 1 . & \text { Rumus nilai Indeks Kepuasan Masyarakat (IKM) }
\end{array}
$$

Untuk memperoleh nilai Survei Kepuasan Masyarakat (SKM) unit pelayanan digunakan pendekatan nilai rata - rata tertimbang dengan rumus pada Gambar 2.

$$
\mathrm{SKM}=\frac{\text { Total dari nilai persepsi per unsur }}{\text { Total unsur yang terisi }} \mathrm{X} \text { nilai penimbang }
$$

Gambar 2.

Rumus nilai Survei Kepuasan Masyarakat (SKM)

Untuk memudahkan interpretasi terhadap penilaian Indeks Kepuasan Masyarakat (IKM) yaitu antara 25 - 100 maka hasil penilaian tersebut di atas dikonversikan dengan nilai dasar 25, dengan rumus pada Gambar 3. 


\section{SKM Unit Pelayanan X 25}

\section{Gambar 3.}

Rumus interpretasi Indeks Kepuasan Masyarakat (IKM)

Mengenai Nilai Persepsi, Nilai Interval, Nilai Interval Konversi Mutu Pelayanan dan Kinerja Unit Pelayanan sesuai berdasarkan Tabel 1.

Tabel 1.

Nilai persepsi, nilai interval, nilai interval konversi mutu pelayanan dan kinerja unit pelayanan

\begin{tabular}{ccccc}
$\begin{array}{c}\text { Nilai } \\
\text { persepsi }\end{array}$ & $\begin{array}{c}\text { Nilai interval } \\
\text { IKM }\end{array}$ & $\begin{array}{c}\text { Nilai interval } \\
\text { konversi IKM }\end{array}$ & $\begin{array}{c}\text { Mutu } \\
\text { pelayanan }\end{array}$ & $\begin{array}{c}\text { Kinerja unit } \\
\text { pelayanan }\end{array}$ \\
\hline 1 & $1.00-2.59$ & $25.00-64.99$ & $\mathrm{D}$ & Tidak baik \\
2 & $2.60-3.05$ & $65.00-76.60$ & $\mathrm{C}$ & Kurang baik \\
3 & $3.06-3.52$ & $76.61-88.30$ & $\mathrm{~B}$ & Baik \\
4 & $3.53-4.00$ & $88.31-100.00$ & $\mathrm{~A}$ & Sangat baik \\
\hline
\end{tabular}

Sumber: Permenpan RB RI nomor 14

\section{Hasil dan Pembahasan}

\section{Kinerja pelayanan pengurusan SIM berbasis teknologi informasi di Satpas Polresta Sidoarjo}

Untuk melihat pelayanan prima pada pelayanan Pengurusan SIM berbasis teknologi informasi di Kantor Polresta Sidoarjo, penulis menggunakan 9 indikator pelayanan prima menurut Bob Livingston (2008) sebagai berikut:

\section{Melebihi harapan}

Indikator ini mencakup penyesuaian standar pelayanan, pemahaman terhadap keinginan pelanggan, dan pelayanan sesuai harapan petugas dalam hal ini pelayanan prima adalah semua aktivitas karyawan yang berkaitan dengan upaya mendengarkan dan memahami kebutuhan pelanggan, mengamati perilaku pelanggan, serta mencurahkan perhatian sepenuhnya kepada pelanggan.

Untuk mengakomodir pelayanan berbasis teknologi informasi saat ini Satpas Polresta Sidoarjo telah memakai sistem registrasi SIM yang berbasis online menggunakan aplikasi e-SIM Sidoarjo. Tidak hanya mengenai feed back yang positif saja, aplikasi baru berupam e-SIM Sidoarjo ini juga menuai beberapa keluhan di antaranya seringnya aplikasi ini mengalami trouble, force close atau beberapa link tidak bisa dibuka, menu kurang lengkap, serta terkadang tidak bisa dibuka untuk jenis HP tertentu. Menurut penulis, peningkatan performa aplikasi ini harus terus dikembangkan. Perlu ada kerjasama dengan Pihak ketiga yang benar-benar berkompeten untuk melakukan pengembangan aplikasi.

\section{Menyelesaikan konflik dan memecahkan masalah}

Indikator ini merupakan kesigapan petugas jika terjadi masalah-masalah dalam melayani masyarakat. Kesigapan ini ditunjukkan dengan adanya petugas yang peka tehadap situasi yang memungkinkan konflik bisa terjadi.

Untuk saat ini konflik dan masalah dalam pengurusan SIM di Kantor Polresta Sidoarjo belum pernah terjadi tetapi sebenarnya problem yang sering terjadi bukan pada pelayanan kepada masyarakat ataupun kinerja para petugas Polresta Sidoarjo, melainkan masalah pendataan dalam pengurusan SIM tersebut dikarenakan pengurusan SIM yang bersifat online, hal tersebut kadang menjadi masalah 
internal petugas Polresta Sidoarjo. Jaringan yang kadang lambat atau terputus merupakan problem dalam pengurusan SIM online, jadi cepat atau tidaknya pengurusan SIM di Samsat Polresta Sidoarjo ditentukan oleh jaringan nirkabel yang harus dipantau agar tetap stabil.

\section{Menangani pengaduan}

Pada saat ini, tidak ada seorangpun yang mau untuk menunggu untuk mendapatkan layanan dan transaksi, karena ini akan menghasilkan keterlambatan pelayanan yang menginginkan pelayanan yang sama pada waktu yang sama. Dalam layanan SIM di Satpas Polresta Sidoarjo saat ini keluhan tentang kesalahan nama dalam registrasi maupun golongan SIM, keluhan lain yang sering diadukan pada pelayanan pengaduan pengurusan SIM di Polresta Sidoarjo yakni soal ujian teori. Rata-rata mereka mengeluhkan soal ujian teori yang masih sulit dan waktu singkat yang diberikan saat mengerjakan ujian teori.

Dari observasi penulis untuk saat ini seharusnya penanganan keluhan atau pengaduan bisa diintegrasikan menjadi satu form aduan adalam aplikasi e-SIM Sidoarjo. Operator aplikasi e-SIM Sidoarjo harus bisa mengorganisir berbagai keluhan untuk selanjutnya meneruskan keluhan tersebut pada Pimpinan untuk memberikan solusi terbaik dan kemudian hasil solusi tersebut selain sebagai bahan evaluasi juga sebagai jawaban atas apa yang dikeluhkan oleh masyarakat.

\section{Berkomunikasi dengan baik}

Salah satu aspek penting dalam pelaksanaan pelayanan publik adalah kemampuan seorang petugas layanan dalam berinteraksi dan berkomunikasi dengan orang lain. Untuk saat ini disimpulkan dalam indikator berkomunikasi dengan baik yang diberikan oleh petugas Satpas Polresta Sidoarjo di Satpas sudah memberikan pelayanan yang baik, hal ini ditandai dengan sikap dan keramahan petugas dalam berkomunikasi dengan masyarakat yang ingin membuat SIM maupun dalam menghadapi keluhankeluhan masyarakat. Tetapi memang kendala saat ini adalah pada peyampaian keluhan, pertanyaan atau berbagai komunikasi interaktif belum bisa didapatkan masyarakat melalui aplikasi e-SIM Sidoarjo.

\section{Fokus pada pelanggan yang dilayani}

Dalam indikator ini fokus pada pelanggan yang dilayani adalah suatu hal yang penting. Seperti contoh jika masyarakat yang lebih awal datang minta dilayani duluan tetapi di saat yang sama keluarga dekat juga datang meminta untuk dilayani duluan dan di saat yang sama juga kerabat dekat juga datang, akhirnya petugas sendiri pun akan bingung siapa yang akan duluan dilayani, apakah masyarakat yang lebih duluan datang, keluarga atau kerabat dekat. Satu-satunya cara mengatasi itu semua adalah fokus pada diri sendiri. Pusatkan perhatian pada pelanggan adalah salah satu cara fokus pada pelanggan yang dilayani. Caranya adalah memberikan pelayanan yang efesien. Saat ini dari penelitian diketahui bahwa fokus petugas Polresta Sidoarjo dalam melayani masyarakat yang ingin mengurus SIM sudah bagus. Fokus utama petugas dalam melayani masyarakat yakni melayani masyarakat dengan cepat dan efesien.

\section{Pemberdayaan}

Pemberdayaan (empowerment) yang dapat dianggap sebagai suatu pendekatan manajemen yang berorientasi pada proses pengalihan kewenangan dan tanggungjawab dari pemegang kekuasaan kepada anggota organisasi, dengan cara menstimulasi, mendorong dan memotivasi mereka agar menjadi lebih berdaya dan mampu mencapai tujuan bersama.

Mengenai pemberdayaan ini Satpas Polresta Sidoarjo mempunyai program unggulan yakni program "Minggu Melayani". Program ini adalah suatu program simulasi uji praktek SIM dilaksanakan setiap hari Minggu (dengan pendampingan petugas) dan hari Senin sampai dengan Sabtu (tanpa pendampingan petugas) di parkir timur GOR Delta Sidoarjo. Selain program tersebut, Polresta Sidoarjo juga mempunyai program unggulan lain yang benar-benar memaksimalkan pemberdayaan 
dari anggotanya yakni SIM Corner di Giant City Sidoarjo dan Sim Keliling yang diadakan di Lippo Plaza Sidoarjo, Alun-alun Sidoarjo, Puri Surya Gedangan, Balong Bendo Sidoarjo, Pondok Candra Sidoarjo, Waru Sidoarjo, Pasar Porong Sidoarjo. Berrdasarkan hasil analisis tersebut diketahui bahwa peran pemberdayaan dalam upaya memaksimalkan kinerja para petugas Polresta Sidoarjo sudah berjalan dengan baik, hal ini dibuktikan dengan inisiatif petugas serta visi misi Polresta Sidoarjo dalam meningkatkan kualitas pelayanan prima.

\section{Berbaur dengan semua orang}

Dalam menjalankan konsep pelayanan prima kepada para pelanggan, sikap atau attitude merupakan poin yang utama. Sikap ramah dan sabar dalam melakukan pelayanan kepada konsumen, baik itu pelanggan kelas atas maupun pelanggan kelas bawah harus diterapkan dengan seimbang. Untuk menciptakan kesan yang baik di mata konsumen, maka para pegawai yang berinteraksi langsung dengan konsumen wajib menggunakan bahasa sopan, cekatan dalam menangani keluhan, dan menjadi pelanggan sebagai seorang raja. Pada indikator ini petugas Satpas Polresta Sidoarjo sudah melakukan proses pelayanan dengan professional, adil, memberikan pelayanan dengan senyum, dan senantiasa sopan dan ramah dalam berkomunikasi.

\section{Mengatur waktu}

Dalam indikator mengatur waktu, petugas Polresta Sidoarjo dituntun untuk mengatur waktu dalam proses pelayanan SIM di Polresta Sidoarjo, salah satu cara untuk mengatur proses pelayanan yaitu dengan ketepatan waktu saat proses pelayanan dilakukan. Saat ini akses masuk menggunakan sistem elektronik dan antrian digital menjadikan rata-rata ketentuan waktu yang dibutuhkan dalam proses melayani pemohon SIM mulai dari registrasi, identifikasi sekitar 3-5 menit untuk waktu pelayanan. Sedangkan ujian teori memakan waktu 30 menit sesi pencerahan dan pengerjaan soal 15 menit. Begitupun dengan ujian praktek memakan waktu 15 menit. Ujian teori di Satpas Polresta Sidoarjo diberlakukan dengan waktu yang presisi dikarenakan dilakukan dengan sistem online yang terintegrasi dengan server. Jadi saat ini indikator mengatur waktu pelayanan yang diberikan oleh Polresta Sidoarjo sudah tergolong tepat waktu dalam melayani pemohon SIM. Hal ini dikarenakan sistem berbasis teknologi informasi yang telah diterapkan dengan baik sehingga proses pelayanan pemohon yang tepat dan tidak mengulur- ngulur waktu, sehingga tidak menunda-nunda apa yang telah dijadwalkan dan dijanjikan kepada pemohon SIM.

\section{Bisa dipercaya}

Dalam pelayanan publik kepercayaan hal yang penting, dari sikap bisa dipercaya ini akan membuat seseorang di mata pelanggan/konsumen merasa nyaman dilayani (Wicaksana 2018; Utomo 2018; Haiti 2018). Trust secara umum dapat diartikan sebagai kepercayaan kepada pihak lain dikarenakan pihak tersebut dapat dipercaya. Seseorang atau organisasi dapat dipercaya karena mempunyai integritas yang tinggi yang dihubungkan dengan kualitas seperti konsisten, berkompeten, jujur, adil, bertanggung jawab, trouble solver, dan baik hati (kebajikan).

Berdasarkan indikator bisa dipercaya misalnya mengenai sikap "adil", dalam hal ini sudah ditunjukkan dengan sikap petugas dalam melayani pemohon meskipun pemohon SIM tersebut dari kalangan atas dan bawah, sikap komunikasi yang sopan dan ramah juga ditunjukkan oleh petugas saat melayani. Sikap "bertanggung jawab" sudah ditunjukkan oleh petugas Satpas Polresta Sidoarjo dengan terus melakukan pelayanan selama jam kerja dan tidak melakukan kegiatan lain selama jam pelayanan, Karena melayani adalah ibadah maka penting mengutamakan orang lain dari pada diri sendiri. Sikap "baik hati" juga ditunjukkan petugas saat melayani pemohon SIM, hal ini ditunjukkan saat melayani masyarakat dari berbagai kalangan, begitupun dalam proses melayani. Sikap yang tidak membanggakan pangkat dan memposisikan dirinya sama dengan orang lain merupakan salah satu bukti bahwa kerendahan hati adalah hal yang penting dalam mendapatkan kepercayaan. Sikap "konsisten" juga ditunjukkan saat proses melayani pemohon SIM. 


\section{Pemantauan evaluasi dan mekanisme pelaporan hasil penilaian Indeks Kepuasan Masyarakat (IKM) terhadap kinerja pelayanan}

Data pendapat masyarakat yang diambil sebagai penetapan pengambilan sampel pengukuran sebanyak 150 responden yang telah menginput atau telah menyalurkan aspirasinya dengan pendapatnya pada aplikasi elektronik survei yang disusun dengan mengkompilasikan data responden untuk dihimpun berdasarkan kelompok umur, jenis kelamin, pendidikan terakhir dan pekerjaan utama. Informasi ini dapat digunakan untuk mengetahui profil responden dan kecenderungan jawaban yang diberikan sebagai bahan analisis obyektivitas, berikut data karakteristik gender, usia dan pekerjaan utama responden sebagai berikut: (1) berdasarkan gender/jenis kelamin responden: a) responden laki-laki sebanyak 110 atau $73.33 \%$; b) responden wanita sebanyak 40 atau 26,67 \%; (2) berdasarkan pekerjaan utama responden: a) responden berusia di atas 40 tahun sebanyak 51 orang atau $41,33 \%$; b) esponden berusia di bawah 40 tahun sebanyak 87 orang atau 58.67\%; (3) berdasarkan pekerjaan utama responden: a) sebagai PNS/TNI/POLRI sebanyak 26 responden atau $17.33 \%$; b) sebagai pegawai swasta sebanyak 50 responden atau 33,33\%; c) sebagai wiraswasta/wirausaha sebanyak 29 responden atau $19.33 \%$; d) sebagai pekerjaan lainnya sebanyak 18 responden atau $12,00 \%$; e) sebagai pelajar atau mahasiswa sebanyak 273 responden atau $18.00 \%$.

Berdasarkan hasil analisis akumulasi data tersebut, informasi penting yang dapat disampaikan antara lain: (1) Hasil nilai rata-rata elektronik survei per unit pelayanan per unsur pelayanan dan nilai IKM per unsur pelayanan pada tabel tersebut diatas, akhirnya bisa diakumulasikan nilai yang mendapatkan nilai skor paling rendah dan harus dilakukan upaya perbaikan layanan yang terdapat pada unsur nomor 8 yakni tentang sarana dan prasarana, kualitas sarana dan prasarana dengan mendapatkan nilai rata-rata per unsur 3,76 \% dan nilai IKM per unsur 10,44 \%, sedangkan yang mendapatkan nilai skor paling tinggi terdapat pada unsur no. 6 tentang kompetensi pelaksana/ kemampuan petugas dalam memberikan pelayanan dengan mendapatkan nilai rata-rata per unsur $3,85 \%$ dan nilai IKM per unsur $10,69 \%$, sudah sangat baik dan memuaskan bagi penerima layanan, sehingga nilai tersebut untuk tetap di pertahankan dan ditingkatkan; (2) Hasil nilai unsur pelayanan dengan nilai terendah dan perlu dilakukan tindak lanjut perbaikan pada pertanyaan unsur no. 8 yaitu: sarana dan prasarana. Adapun tindaklanjut dari pertanyaan pada unsur no. 8 tersebut menurut Kasat Lantas Polresta Sidoarjo sebagai pimpinan penyelenggara pelayanan di satpas dengan menindaklanjuti atas hasil kesimpulan data survei dari unsur terendah tentang sarana prasarana.

Adapun tindak lanjut atau upaya perbaikan sarana dan prasana yang telah dilaksanakan Kasat Lantas Polresta Sidoarjo sebagai berikut: a) Pemasangan digital doorlock pintu utama satpas; b) Penambahan ruang tunggu bagi keluarga/pengantar; c) Penambahan 1 unit AC diruang tunggu pendaftaran SIM; d) Pembangunan tempat Tunggu peserta uji praktek roda dua dan roda empat; e) Penambahan fasilitas kursi ruang tunggu smoking area; f) Penambahan fasilitas perangkat e-IKM dengan mesin kiosk; g) Pembuatan parkir dan jalur rambatan khusus disabilitas di satpas; h) Pembuatan toilet khusus disabilitas; i) Penambahan kursi di ruang tunggu pendaftaran; j) Penambahan tempat tunggu khusus lansia; k) Pembuatan jalur evakuasi dan titik kumpul; l) Penambahan sarana informasi pelayanan dengan stiker one way di kaca; $m$ ) Penambahan informasi berbentuk spanduk transparasi layanan seperti biaya, prosedur, waktu layanan di area satpas; $n$ ) Pemberian dispenser air mineral dingin dan panas di ruang tunggu pengantar, ruang tunggu pendaftaran dan di ruang pojok baca; o) Pembuatan arena tempat bermain khusus anak-anak yang nyaman dan representatif di ruang tunggu pelayanan Satpas Polresta Sidoarjo; p) Pembuatan sarana dan prasarana lapangan latihan uji praktek SIM program satu kecamatan satu lapangan latihan uji praktek SIM, adapun tujuan inovasi tersebut sebagai program untuk mendekatkan pelayanan kepada masyarakat yang jauh dari Kantor Satpas Polresta Sidoarjo dengan memberikan kemudahan kepada masyarakat yang telah gagal dalam uji praktek SIM maupun yang ingin memiliki SIM baru dengan menyediakan sarana prasarana latihan uji praktek SIM yang dekat sama tempat tinggalnya dan tidak perlu lagi datang jauh-jauh ke kantor Satpas Polresta Sidoarjo hanya untuk berlatih uji SIM. 
Beberapa faktor yang berpengaruh terhadap hasil penilaian mengalami peningkatan pada hasil elektronik survei kepuasan masyarakat (e-SKM) semester II tahun 2018, berdasarkan observasi penulis antara lain: (1) Tersedianya akses keterbukaan informasi layanan berbentuk papan/media tentang prosedur/mekanisme, persyaratan, waktu pelayanan dan biaya sesuai PP. No. 60 Tahun 2016 yang telah terpasang ditempat pelayanan satpas. Petugas yang tersprint secara rutinitas telah melaksanakan sosialisasi/pencerahan kepada pemohon pendaftar SIM perpanjangan, peserta uji teori/praktek yang dilakukan setiap hari sebelum pelayanan dimulai, serta tersedianya informasi layanan melalui media elektronik dengan berbasis teknologi seperti media sosial, website, blogspot, aplikasi e-SIM Polresta Sidoarjo yang bisa didownload di playstore dan mudah diakses oleh masyarakat dan bersifat responsif terkait pelayanan penerbitan SIM; (2) Kompetensi personil SIM satpas sudah memiliki kemampuan berkat pelatihan dan sertifikasi kompetensi penguji SIM yang dilaksanakan secara bertahap oleh Korlantas Polri dan Lembaga Sertifikasi Profesi (LSP) Polri; (3) Pelayanan buka lebih awal sedangkan waktu pelayanan telah ditetapkan pada pukul 8.00 WIB sudah dimulai, akan tetapi pelayanan satpas Polresta Sidoarjo pelayanan sudah buka pukul 7.30 WIB menunjukkan petugas sangat disiplin, patuh dan berkomitmen terhadap jadwal waktu pelayanan serta petugas Satpas lebih responsif dalam pelaksanaan tugas layanan; (4) Penambahan sarana dan prasarana yang ditunjang dengan lingkungan yang bersih/representatif serta wujud sebagai bentuk pelayanan prima yang terus menerus dilakukan upaya pembenahan yang inovatif untuk memberikan sarana dan prasarana pelayanan yang lebih nyaman kepada masyarakat; (5) Teknik survei kepuasan masyarakat pada satpas Satlantas Polresta Sidoarjo telah mengembangkan inovasi elektronik survei kepuasan masyarakat (e-SKM) berbasis IT sehingga teknik survei ini sangat mendorong masyarakat/responden berpartisipasi mengisi pendapatnya melalui elektronik survei, yang sebelum pengisian kuesioner cara manual dengan mengisi lembar kuesioner yang dibagikan ke pemohon SIM/responden, cara tersebut sangatlah merepotkan dan menggangu waktu responden sehingga kurang efektif serta tidak sistematis dalam pengelolaan data hasil survei.

\section{Simpulan}

Penilaian kinerja penerbitan SIM dengan sistem online dengan prinsip pelayanan prima di Satpas Polresta Sidoarjo dilakukan berdasarkan pada 9 indikator sebagaimana pendapat dari Bob Livingston. Hasil dari indikator tersebut yaitu: "Melebihi harapan", hal ini berkaitan standardisasi pelayanan yang diberikan oleh petugas Polresta Sidoarjo, sikap perhatian dan pelayanan yang bermutu tinggi sehingga kepuasan masyarakat menjadi patokan penting dalam pelayanan yang melebihi harapan. Dalam kriteria ini ada beberapa masyarakat yang kurang puas khususnya mengenai aplikasi e-SIM Sidoarjo yang dirasa masih sering error, mengalami force close, atau kurangnya berbagai menu dalam aplikasi sehingga harapan tinggi masyarakat pada aplikasi ini belum tercapai secara maksimal. Pada indikator "menyelesaikan konflik dan memecahkan masalah" diketahui bahwa konflik yang terjadi maupun masalah-masalah selama proses pelayanan belum ada tapi masalah teknis seperti jaringan internet mati. Hal ini tentunya kendala yang sangat berarti karena lancarnya jaringan internet adalah faktor utama dari kelancaran administratif SIM online.

Dalam hal "menangani pengaduan" saat ini aduan yang dihadapi petugas saat melayani keluhankeluhan masyarakat yakni kesalahan nama, golongan SIM yang salah dan keluhan mengenai ujian teori. Saat ini aduan tidak bisa dilakukan secara online melalui aplikasi E-SIM Sidoarjo. Padahal menurut penulis aduan secara online penting untuk diintegrasikan dalam aplikasi tersebut untuk memaksimalkan layanan pada masyarakat. Pada indikator "berkomunikasi dengan baik" menunjukkan bahwa sikap ramah sudah dilaksanakan oleh petugas saat proses pelayanan pengurusan SIM. Tetapi memang kendala saat ini adalah pada peyampaian keluhan, pertanyaan atau berbagai komunikasi interaktif belum bisa didapatkan masyarakat melalui aplikasi e- SIM Sidoarjo.

Pada indikator "Fokus pada pelanggan yang dilayani" memaparkan bahwa fokus petugas dalam melayani bisa dilihat dari pelayanan yang cepat dan efisien begitupun peraturan yang melarang ada kegiatan lain saat jam pelayanan. Untuk indikator "Pemberdayaan" diketahui bahwa peran petugas dalam melayani sudah dibagi-bagi berdasarkan job desc yang sudah ditentukan. Sedangkan dalam indikator "berbaur dengan semua orang", petugas dituntut untuk bisa melayani semua kalangan 
masyarakat. "Mengatur waktu", petugas harus bisa tepat waktu dalam melayani masyarakat. "Bisa dipercaya" pada indikator terakhir petugas harus menjadi sosok yang bijaksana, tegas, jujur, dan transparan dalam melayani agar masyarakat bisa merasa nyaman dalam mengurus SIM.

\section{Daftar Pustaka}

Al-Nuami ITI, Mahmood AK \& Jebur HH (2014) Proposed conceptual model for e-service quality in malaysian universities. Dalam Conference Paper IEEE, 16 -17 Juni 2014, Malaysian Universitites.

Angguna YP, Gani AYA \& Sarwono (2016) Upaya pengembangan e-government dalam pelayaan publik pada Dinas Koperasi dan UKM Kota Malang. Jurnal Administrasi Publik 3(1):80-88.

Haiti FA (2018) Peran anggota Satuan Reserse Kriminal dalam menanggulangi kejahatan jalanan. Jurnal Sosiologi Dialektika 13 (2):141-151.

Bressolles G \& Nantel J (2008) The measurement of electronic service quality: Improvements and application. International Journal of e-Business Research 4 (3):1-19.

Dewanto RDK (2018) Penegakan hukum terhadap korporasi sebagai pelaku tindak pidana lingkungan hidup di wilayah hukum Sidoarjo. Jurnal Sosiologi Dialektika 13 (2):183-192.

Fahlefi Z (2014) Penerapan teknologi informasi bagi pelaksanaan pelayanan publik (studi pada BP2TSP Kota Samarinda). Jurnal Paradigma 3 (2):155-166.

Fassnacht M \& Koese I (2006) Quality of electronic service: conceptulizing and testing a hierarchical model. Journal of Service Research 9 (1):19-37.

Febrianti L \& Maulana H (2013) Pengaruh persepsi masyarakat pada kinerja kepolisian terhadap kepercayaan pada kepolisian. Jurnal Penelitian dan Pengukuran Psikologi 2 (1):63-71.

Gemilang C (2016) Implementasi pelayanan prima dalam pembuatan Surat Izin Mengemudi (SIM) di Polresta Samarinda. E-Journal Adminitrasi Negara 4 (1):2479-2492.

Indrajit RE (2006) Elektronic Government: Strategi Pembangunan dan Pengembangan Sistem Pelayanan Publik Berbasis Teknologi Digital. Yogyakarta: ANDI.

Iswahyudi (2014) Kualitas Layanan Kantor Imigrasi Kelas 1 Yogyakarta dalam Pembuatan Paspor Berbasis E-Goverment (Studi Kasus Pada Kantor Imigrasi Kelas 1 Yogyakarta). Yogyakarta: Universitas Muhammadiyah Yogyakarta.

Juwita A (2018) Optimalisasi SIM online sebagai strategi untuk mewujudkan pelayanan prima pada kantor Satpas Jember. Airlangga Development Journal 2 (2):1-23.

Lee GG \& Lin HF (2005) Customer perception of e-service quality in online shopping. International Journal of Retail \& Distribution Management 33 (2):161-176.

Livingston B (2008) Create Service Excellence That Wins Client for Life. USA.

Mangkunegara AP (2009) Manajemen Sumber Daya Manusia Perusahaan, Penulis: Anwar Prabu Mangkunegara. Bandung: Rosda.

Moleong LJ (2014) Metode Penelitian Kualitatif. Bandung: PT Remaja Rosdakarya.

Mukarom Z (2015) Manajemen Pelayanan Publik. Bandung: Pustaka Setia.

Prabowo TL \& Irwansyah (2018) Media digital Polisiku: Pelayanan publik Polri kepada masyarakat. Jurnal Studi Komunikasi 14 (3):539-546.

Silalahi U (2011) Asas-asas Manajemen. Bandung: Refika Aditama.

Sinambela LP (2006) Reformasi Pelayanan Publik: Teori, Kebijakan, dan Implementasi. Jakarta: Bumi Aksara.

Sinambela LP (2014) Reformasi Pelayanan Publik. Jakarta: Bumi Aksara.

Sunanto S, Taufiqurrahman T \& Pangemanan R (2007) An analysis of university e-service quality gap and student satisfaction in Indonesia. The International Journal of Knowlwdge, Culture, and Change Management 7 (7):1-10.

Susanti G (2006) E-Government dalam pelayanan publik. Visi Jurnal Ilmu Administrasi Fisip Universitas Hassanuddin 7 (2):18-29.

Tejo GA \& Machasin (2015) Pengaruh kompetensi dan budaya organisasi terhadap motivasi kerja serta dampaknya terhadap kinerja personel bidang humas Polda Riau. Jurnal Tepak Manajemen Bisnis 7 (3):437-454.

Utomo AS (2018) Peranan satgas Dwelling Time Polres Pelabuhan Tanjung Perak terhadap penurunan angka Dwelling Time. Jurnal Sosiologi Dialektika 13 (2):132-140. 
Wicaksana AR (2018) Kewenangan tembak di tempat oleh aparat kepolisian terhadap pelaku kejahatan. Jurnal Sosiologi Dialektika 13 (2):114-121.

Wiyono TS, Saputra R \& Sarwoko EA (2012) pengembangan sistem informasi pendaftaran Surat Izin Mengemudi online. Journal of Informatics and Technology 1 (1):52-62.

Yih Goh C, Wei Ong J, Zhuang Tan S, Guan Guan Goh G \& Cyril Eze U (2011) E-service quality and user satisfaction toward e-filling. International Journal on Social Science, Economic and Art $2(2): 50-54$. 